\title{
TINJAUAN HUKUM PEMLIKAN APARTEMEN (SATUAN RUMAH SUSUN) OLEH ORANG ASING / WARGA NEGARA ASING DI INDONESIA
}

\author{
Oleh :

\section{Selamat Lumban Gaol} \\ Dosen Tetap Fakultas Hukum Universitas Dirgantara Marsekal Suryadarma, aktif di LKBH Unsurya, \\ anggota PERADI (Perhimpunan Advokat Indonesia) dan anggota HKHPM (Himpunan Konsultan Hukum Pasar \\ Modal), serta Mediator bersertipikat dari Mahkamah Agung R.I. dan terdaftar di beberapa \\ Pengadilan Negeri sebagai Mediator Non Hakim \\ Email : selamatlumbangaol@gmail.com
}

\begin{abstract}
Abstrak
Kepadatan penduduk di kota-kota besar selain pertumbuhan dan pertambahan penduduk lokal (WNI), juga dikarenakan adanya pekerja asing (orang/WNA) yang berkerja di Indonesia, sehingga membutuhkan tempat tinggal baik yang horizontal maupun yang vertikal (rumah susun), baik karena didasarkan hubungan sewa menyewa ataupun didasarkan kepemilikan yang tunduk kepada ketentuan hukum nasional Indonesia sesuai dengan asas nasionalitas. Permasalahan hukum yang timbul bagaimanakah pengaturan hukum pemilikan satuan rumah susun (apartemen, kondominium) oleh orang Asing / WNA di Indonesia dan apakah orang Asing / WNA dapat memiliki satuan rumah susun di Indonesia ?. Untuk menjawab persoalan tersebut dalam penelitian ini metode penelitian yuridis normatif dan pendekatan Undang-Undang (statute approach), serta menggunakan data sekunder. Pengaturan hukum pemilikan apartemen oleh orang asing / WNA di Indonesia telah cukup memadai, karena telah diatur dalam UU No. 20 Tahun 2011, PP No. 103 Tahun 2015 maupun Permen ATR/Ka.BPN No. 29 Tahun 2016, dan Orang Asing/WNA dapat memiliki satuan rumah susun yang dibangun dan berdiri hanya di atas bidang tanah hak pakai atas tanah negara
\end{abstract}

Kata Kunci : rumah susun, warga negara Asing, Pemilikan.

\section{PENDAHULUAN}

\section{A. Latar Belakang Permasalahan}

Pada awalnya, manusia mendiami atau tinggal di atas permukaan bidang tanah untuk bercocok tanam dan mendirikan bagunan sebagai tempat tinggal bagi dirinya maupun keluarganya, akan tetapi seiring dengan pertumbuhan dan pertambahan penduduk disatu sisi, dan lahan atau tanah yang tersedia relatif terbatas dan tetap disisi lain, sehingga kemudian orang mulai memikirkan dan membangun bagunan bertingkat dengan sistem satuan baik untuk hunian atau non hunian (rumah susun). ${ }^{1}$

Pembangunan rumah susun akan dapat mengurangi penggunaan tanah akibat pembangunan rumah tinggal secara horizontal, dan mendekatkan penghuni rumah susun ke daerah

${ }^{1}$ Imam Kuswahyono, Hukum Rumah Susun : Suatu Bekal Pengantar Pemahaman, Cet. 1, (Malang : Bayu Media Publishing, 2004), hlm. 1. 
tempat kerjanua memperpendek jaringan sarana prasarana serta pemanfaatan kota dengan membuat ruang-ruang terbuka kota yang lebih lega dan nyaman. ${ }^{2}$

Kepadatan penduduk di kota-kota besar selain pertumbuhan dan pertambahan penduduk lokal (Warga Negara Indonesia), juga dikarenakan adanya pekerja asing (warga negara Asing) yang berkerja di Indonesia. Orang / warga negara Asing yang bekerja di Indonesia tersebut tentunya membutuhkan tempat tinggal baik yang horizontal maupun yang vertikal (rumah susun), baik karena didasarkan hubungan sewa menyewa ataupun didasarkan kepemilikan.

Pemilikan atas tanah beserta bangunan diatasnya, termasuk juga pemilikan satuan rumah susun oleh Orang / warga negara Asing yang ada di Indonesia tunduk kepada ketentuan hukum nasional Indonesia sesuai dengan asas nasionalitas.

Asas nasionalitas ini dalam bidang agraria semula diatur dan berlaku dalam hukum tanah nasional Indonesia, lalu dalam bidang pembangunan perumahan dan pemukiman serta terakhir dalam penyelenggaraan rumah susun.

Dalam hukum tanah nasional Indonesia asas nasionalitas sebagai satu kesatuan wilayah teritorial maupun kewarganegaraan subjek pemegang hak atas tanah adalah Warga Negara Indonesia tunggal, diatur dalam Undang-Undang Nomor 5 Tahun $1960^{3}$

\section{${ }^{2} \mathrm{Tbid}$., hlm. 3.}

${ }^{3}$ Indonesia, Undang-Undang Tentang Peraturan Dasar Pokok-Pokok Agraria, UU Nomor 5 Tahun 1960, Lembaran Negara Republik Indonesia
Tentang Peraturan Dasar Pokok-Pokok Agraria khususnya Pasal 1 ayat (1) ${ }^{4}$ serta Pasal 21 ayat (1) dan ayat (4). ${ }^{5}$

Lebih lanjut dalam Undang-Undang Nomor 1 Tahun 2011 Tentang Perumahan Dan Kawasan Permukiman $^{6}$ diatur Pasal 2 sub huruf $\mathrm{c}$ bahwa Perumahan dan kawasan permukiman diselenggarakan dengan berasaskan kenasionalan. ${ }^{7}$

Demikian pula dalam UndangUndang Nomor 20 Tahun 2011 Tentang Ruman Susun ${ }^{8}$ diatur Pasal 2

Tahun 1960 Nomor 104, Tambahan Lembaran Negara Republik Indonesia Nomor 2043), untuk selanjutnya dalam penulisan ini disebut / ditulis "UU No. 5 Tahun 1960," atau "UU Pokok Agraria," atau "UU PA." UU No. 5 Tahun 1960 ini mulai berlaku sejak tanggal 24 September 1960.

${ }^{4}$ UU No. 5 Tahun 1960, Pasal 1 ayat (1)

"Seluruh wilayah Indonesia adalah kesatuan tanah-air dari seluruh rakyat Indonesia yang bersatu sebagai bangsa Indonesia."

${ }^{5}$ UU No. 5 Tahun 1960, Pasal 21 ayat (1) "Hanya warga negara Indonesia dapat mempunyai hak milik." ; Ayat (4) "Selama seseorang disamping kewarganegaraan Indonesianya mempunyai kewarganegaraan asing maka ia tidak dapat mempunyai tanah dengan hak milik dan baginya berlaku ketentuan dalam ayat (3) pasal ini.'

${ }^{6}$ Indonesia, Undang-Undang Tentang Perumahan Dan Kawasan Permukiman, UU Nomor 1 Tahun 2011, Lembaran Negara Republik Indonesia Tahun 2011 Nomor 17, Tambahan Lembaran Negara Republik Indonesia Nomor 5188), untuk selanjutnya dalam penulisan ini disebut / ditulis "UU No. 1 Tahun 2011," atau "UU Perumahan Dan Permukiman," atau "UU Perumahan." UU No. 1 Tahun 2011 ini mulai berlaku sejak tanggal 12 Januari 2011.

${ }^{7}$ UU No. 1 Tahun 2011, Penjelasan Pasal 2 sub huruf c "Yang dimaksud dengan "asas kenasionalan" adalah memberikan landasan agar hak kepemilikan tanah hanya berlaku untuk warga negara Indonesia, sedangkan hak menghuni dan menempati oleh orang asing hanya dimungkinkan dengan cara hak sewa atau hak pakai atas rumah."

${ }^{8}$ Indonesia, Undang-Undang Tentang Rumah Susun, UU Nomor 20 Tahun 2011, Lembaran Negara Republik Indonesia Tahun 2011 Nomor 108, 
sub huruf c bahwa penyelenggaraan rumah susun berasaskan pada kenasionalan, ${ }^{9}$ yang mencabut dan menggantikan Undang-Undang Nomor 16 Tahun $1985^{10}$ tentang Rumah Susun.

Orang / warga negara Asing yang ada di Indonesia dimungkinkan untuk membeli dan memiliki satuan rumah susun yang dibangun dan berdiri diatas hak atas tanah tertentu diatur dalam Peraturan Pemerintah Nomor 103 Tahun 2015 $5^{11}$ tentang Pemilikan Rumah Tempat Tinggal atau Hunian oleh Orang Asing yang Berkedudukan di Indonesia, yang mencabut dan menggantikan Peraturan Pemerintah Nomor 41 Tahun $1996^{12}$ tentang

Tambahan Lembaran Negara Republik Indonesia Nomor 5252), untuk selanjutnya dalam penulisan ini disebut / ditulis "UU No. 20 Tahun 2011," atau "UU Rumah Susun," atau "UU RS." UU No. 20 Tahun 2011 ini mulai berlaku sejak tanggal 10 November 2011.

${ }^{9}$ UU No. 20 Tahun 2011, Penjelasan Pasal

2 sub huruf c "Yang dimaksud dengan "asas kenasionalan" adalah memberikan landasan agar kepemilikan sarusun dimanfaatkan sebesar-besarnya untuk kepentingan nasional."

${ }^{10}$ Indonesia, Undang-Undang Tentang Rumah Susun, UU Nomor 16 Tahun 1985, Lembaran Negara Republik Indonesia Tahun 1985 Nomor 75, Tambahan Lembaran Negara Republik Indonesia Nomor 3318), untuk selanjutnya dalam penulisan ini disebut / ditulis "UU No. 16 Tahun 1985," atau "UU Rumah Susun 1985," atau "UU RS 1985." UU No. 16 Tahun 1985 ini mulai berlaku sejak tanggal 31 Desember 1985.

${ }^{11}$ Indonesia, Peraturan Pemerintah Tentang Pemilikan Rumah Tempat Tinggal atau Hunian oleh Orang Asing yang Berkedudukan di Indonesia, PP Nomor 103 Tahun 2015, Lembaran Negara Republik Indonesia Tahun 2015 Nomor 325, Tambahan Lembaran Negara Republik Indonesia Nomor 5793), untuk selanjutnya dalam penulisan ini disebut / ditulis "PP No. 103 Tahun 2015," atau "PP Pemilikan Rumah Tinggal Oleh Orang Asing." PP No. 103 Tahun 2015 ini mulai berlaku sejak tanggal 28 Desember 2015.

${ }^{12}$ Indonesia, Peraturan Pemerintah Tentang Pemilikan Rumah Tempat Tinggal atau Hunian oleh Orang Asing yang Berkedudukan di Indonesia, PP Nomor 41 Tahun 1996, Lembaran Negara Republik Indonesia Tahun 1996 Nomor 59, Tambahan
Pemilikan Rumah Tempat Tinggal atau Hunian oleh Orang Asing yang Berkedudukan di Indonesia.

Dari uraian diatas timbul suatu kegelisahan akademik berkenaan dengan pengaturan hukum Pemilikan Apartemen (satuan rumah susun) Oleh Orang Asing / Warga Negara Asing Di Indonesia.

Berdasarkan latar belakang masalah tersebut, peneliti melakukan penelitian dengan judul "Tinjauan Hukum Pemilikan Apartemen (satuan rumah susun) Oleh Orang Asing / Warga Negara Asing Di Indonesia."

\section{B. Rumusan Masalah}

Bertolak dari uraian latar belakang permasalahan tersebut, dapat dirumuskan permasalahan yang akan dikaji dalam penelitian ini dibatasi pada pokoknya sebagai berikut:

1. Bagaimanakah pengaturan hukum pemilikan apartemen (satuan rumah susun) oleh orang Asing / warga negara Asing?

2. Apakah orang Asing / warga negara Asing dapat memiliki apartemen (satuan rumah susun) di Indonesia?.

\section{Tujuan dan Kegunaan}

Secara teoritis penelitian ini diharapkan dapat mengembangkan ilmu pengetahuan hukum pada umumnya, khususnya hukum perdata dan hukum agraria di Indonesia terkait dengan masalah pemilikan apartemen (satuan rumah susun) oleh orang Asing

Lembaran Negara Republik Indonesia Nomor 3644, untuk selanjutnya dalam penulisan ini disebut / ditulis "PP Nomor 41 Tahun 1996," atau "PP No. 41 Tahun 1996." PP No. 41 Tahun 1996 ini mulai berlaku sejak tanggal 17 Juni 1996. 
/ warga negara Asing. Kemudian diharapkan juga dapat digunakan sebagai referensi yang dapat ikut menunjang ilmu pengetahuan khususnya ilmu pengetahuan hukum perdata Indonesia termasuk di dalamnya hukum agraria, hukum perumahan, hukum apartemen (satuan rumah susun) dan pemilikan apartemen (satuan rumah susun) oleh orang Asing / warga negara Asing. Selanjutnya penelitian ini diharapkan juga dapat berguna secara praktis, yaitu menjadi pegangan dan pedoman bagi praktisi hukum dalam menangani sengketa pemilikan apartemen (satuan rumah susun) oleh orang Asing / warga negara Asing. Penelitian ini juga diharapkan dapat berguna bagi kalangan masyarakat luas ketika hendak mengajukan gugatan ke Pengadilan atas sengketa kepemilikan apartemen (satuan rumah susun) oleh orang Asing / warga negara Asing.

\section{D.Studi Pustaka}

1. Rumah Susun (apartemen ; condominium)

Pengertian rumah susun baik dalam UU No. 16 Tahun 1985 maupun dalam UU No. 20 Tahun 2011 memiliki rumusan yang sama, bahwa Rumah Susun adalah bangunan gedung bertingkat yang dibangun dalam suatu lingkungan yang terbagi dalam bagian-bagian yang distrukturkan secara fungsional, baik dalam arah horizontal maupun vertikal dan merupakan satuan-satuan yang masing-masing dapat dimiliki dan digunakan secara terpisah, terutama untuk tempat hunian yang dilengkapi dengan bagian bersama, benda bersama, dan tanah bersama. ${ }^{13}$

Bukti kepemilikan atas unit satuan rumah susun (SRS) dibuktikan dengan Sertipikat Hak Milik atas Satuan rumah susun (Sertipikat HMSRS). Konsep HMSRS yang terdiri dari hak perseorangan atas unit SRS dan hak bersama atas tanah benda dan bagian bersama yang kesemuanya merupakan satu kesatuan yang tidak terpisahkan dengan satuan-satuan yang bersangkutan merupakan lembaga kepemilikan baru sebagai hak kebendaan dalam sistem hukum Indonesia yang lahir dan diperkenalkan dengan dan dalam UU No. 16 Tahun $1985 .{ }^{14}$

Konsep dasar yang melandasi HMSRS adalah konsep kepemilikan suatu benda oleh lebih dari satu orang, yang dikenal dengan pemilikan bersama yang terdiri dari 2 (dua) bentuk kepemilikan, yaitu: ${ }^{15}$

a. Pemilikan bersama yang terikat (gebonden mede egindom)

Ikatan hukum telah ada terlebih dahulu diantara Para Pemilik benda bersama tersebut, misalnya pemilikan bersama yang terdapat pada harta perkawinan, atau harta peninggalan. Para Pemilik bersama (mede egindom) tidak dapat bebas memindahkan haknya kepada orang lain tanpa

${ }^{13}$ vide Pasal 1 angka 1 UU No. 16 Tahun 1985 dan Pasal 1 angka 1 UU No. 20 Tahun 2011.

${ }^{14}$ Arie S. Hutagalung, Condominium Dan Permasalahannya, Ed. 1, Cet. 1, (Depok : Badan Penerbit Fakultas Hukum Universitas Indonesia, 1998), hlm. 9

${ }^{15}$ Ibid., hlm. 9-11. 
persetujuan mede eigenaar lainnya, atau selama suami isteri masih dalam ikatan perkawinan tidak dimungkinkan mengadakan pemisahan dan pembagian harta perkwinan.

b. Pemilikan bersama yang bebas (vrije mede egindom)

Antara Para pemilik bersama tidak terdapat ikatan huum terlebih dahulu, selain dari hak bersama menjadi pemilik dari suatu benda untuk digunakan bersama.

Bentuk pemilikan bersama yang bebas (vrije mede egindom) inilah yang menurut hukum Romawi disebut condominium yang penerapannya diadopsi dan diatur dalam UU No. 16 Tahun 1985, dimana konsep pemilikan bersama ini dirumuskan suatu jenis pemilikan perseorangan dan pemilikan bersama dalam satu paket jenis pemilikan yang disebut HMSRS.

Dalam konteks HMSRS diatur bahwa hak perseorangan atas Unit SRS meliputi pula hak bersama atas bangunan, benda dan tanahnya. HMSRS lahir sejak didaftarkannya Akta Pemisahan dengan dibuatnya Buku Tanah atas setiap unit SRS yang bersangkutan (vide Pasal 39 ayat (5) Peraturan Pemerintah Nomor 4 Tahun 1988 Tentang Rumah Susun ${ }^{16}$ ), dimana pemilik

${ }^{16}$ Indonesia, Peraturan Pemerintah Tentang Rumah Susun, PP Nomor 4 Tahun 1988, Lembaran Negara Republik Indonesia Tahun 1988 Nomor 7, Tambahan Lembaran Negara Republik Indonesia Nomor 3372), untuk selanjutnya dalam penulisan ini unit SRS yang bersangkutan harus memenuhi syarat sebagai pemegang hak atas tanah.

Untuk menjamin kepastian hak bagi pemilikan SRS, Pemerintah memberikan akat pembuktian yang kuat berupa Sertipikat HMSRS yang diterbitkan oleh Kantor Pertanahan Kabupaten /Kotamdya setempat.

Bagunan rumah susun dapat berdiri diatas bidang tanah dengan hak atas tanah tertentu yang diatur dan tunduk kepada hukum agraria ataupun hukum tanah nasional yang diatur dalam UU No. 5 Tahun 1960 beserta peraturan / ketentuan pelaksanaannya, antara lain, akan tetapi tidak terbatas pada, Peraturan Pemerintah Nomor 38 tahun 1963 Tentang Penunjukan Badan-badan Hukum Yang Dapat Mempunyai Hak Milik Atas Tanah, ${ }^{17}$ Peraturan Pemerintah No. 40 Tahun 1996 tentang Hak Guna Bangunan, Hak Guna Usaha, dan Hak Pakai atas Tanah, ${ }^{18}$ Peraturan Pemerintah Nomor 24 Tahun 1997 tentang

disebut / ditulis "PP No. 4 Tahun 1988," atau "PP Rumah Susun." PP No. 4 Tahun 1988 ini mulai berlaku sejak tanggal 26 April 1988.

${ }^{17}$ Indonesia, Peraturan Pemerintah Tentang Penunjukan Badan-badan Hukum Yang Dapat Mempunyai Hak Milik Atas Tanah, PP Nomor 38 Tahun 1963, Lembaran Negara Tahun 1963 Nomor 61, Tambahan Lembaran Negara Nomor 2555, untuk selanjutnya dalam penulisan ini disebut / ditulis "PP Nomor 38 Tahun 1963," atau "PP No. 38 Tahun 1963."

${ }^{18}$ Indonesia, Peraturan Pemerintah Tentang Hak Guna Bangunan, Hak Guna Usaha, dan Hak Pakai atas Tanah, PP Nomor 40 Tahun 1996, Lembaran Negara Republik Indonesia Tahun 1996 Nomor 58, Tambahan Lembaran Negara Republik Indonesia Nomor 3643, untuk selanjutnya dalam penulisan ini disebut / ditulis "PP Nomor 40 Tahun 1996," atau "PP No. 40 Tahun 1996." 
Pendaftaran Tanah ${ }^{19}$ mencabut dan menggantikan Peraturan Pemerintah Nomor 10 Tahun 1961 tentang Pendaftaran Tanah, ${ }^{20}$ Peraturan Pemerintah Nomor 37 Tahun 1998 Tentang Peraturan Jabatan PPAT ${ }^{21}$ sebagaimana diubah dengan Peraturan Pemerintah Nomor 24 Tahun 2016 ${ }^{22}$ Tentang Perubahan Peraturan Pemerintah Nomor 37 Tahun 1998 Tentang Peraturan Jabatan PPAT.

Selain Peraturan Pemerintah tersebut diatas, ada beberapa aturanaturan teknis yang harus diperhatikan dalam proses

${ }^{19}$ Indonesia, Peraturan Pemerintah Tentang Pendaftaran Tanah, PP Nomor 24 Tahun 1997, Lembaran Negara Republik Indonesia Tahun 1997 Nomor 59, Tambahan Lembaran Negara Republik Indonesia Nomor 3696, untuk selanjutnya dalam penulisan ini disebut / ditulis "PP Nomor 24 Tahun 1997," atau "PP No. 24 Tahun 1997." PP No. 24 Tahun 1997 berdasarkan ketentuan Pasal 66 berlaku 3 (tiga) bulan sejak diundangkan. PP No. 24 Tahun 1997 diundangkan pada tanggal 08 Juni 1997, oleh karenanya PP No. 24 Tahun 1997 mulai berlaku sejak tanggal 08 Oktober 1997.

${ }^{20}$ Indonesia, Peraturan Pemerintah Tentang Pendaftaran Tanah, PP Nomor 10 Tahun 1961, Lembaran Negara Republik Indonesia Tahun 1961 Nomor 28, Tambahan Lembaran Negara Republik Indonesia Nomor 2171, untuk selanjutnya dalam penulisan ini disebut / ditulis "PP Nomor 10 Tahun 1961," atau "PP No. 10 Tahun 1961." PP No. 10 Tahun 1961 mulai berlaku sejak tanggal 23 Maret 1961.

${ }^{21}$ Indonesia, Peraturan Pemerintah Tentang Peraturan Jabatan Pejabat Pembuat Akta Tanah, PP Nomor 37 Tahun 1998, Lembaran Negara Republik Indonesia Tahun 1998 Nomor 52, Tambahan Lembaran Negara Republik Indonesia Nomor 3746, untuk selanjutnya dalam penulisan ini disebut / ditulis "PP Nomor 37 Tahun 1998," atau "PP No. 37 Tahun 1998." PP No. 37 Tahun 1998 mulai berlaku sejak tanggal 05 Maret 1998.

${ }^{22}$ Indonesia, Peraturan Pemerintah Tentang Perubahan Peraturan Pemerintah Tentang Peraturan Jabatan Pejabat Pembuat Akta Tanah, PP Nomor 24 Tahun 2016, Lembaran Negara Republik Indonesia Tahun 2016 Nomor 120, Tambahan Lembaran Negara Republik Indonesia Nomor 5893, untuk selanjutnya dalam penulisan ini disebut / ditulis "PP Nomor 24 Tahun 2016," atau "PP No. 24 Tahun 2016." penerbitan hak atas tanah atas bidang tanah tempat berdirinya bangunan rumah susun tersebut, antara lain, akan tetapi tidak terbatas pada Peraturan Menteri Agraria No. 9 Tahun $1965^{23}$ Tentang Pelaksanaan Konversi Hak Penguasaan Atas Tanah Negara Dan Kebijaksanaan, Peraturan Menteri Negara Agraria / Kepala Badan Pertanahan Nasional Nomor 3 Tahun $1997^{24}$ tentang Ketentuan Pelaksanaan Peraturan Pemerintah Nomor 24 Tahun 1997 tentang Pendaftaran Tanah sebagaimana diubah dengan Peraturan Kepala Badan Pertanahan Nasional Nomor 8 Tahun 2012, ${ }^{25}$ Keputusan Menteri Negara Agraria/Kepala Badan Pertanahan Nasional Nomor 16 Tahun $1997^{26}$ tentang Perubahan

${ }^{23}$ Kementerian Agraria, Peraturan Menteri Agraria Tentang Pelaksanaan Konversi Hak Penguasaan Atas Tanah Negara Dan Kebijaksanaan, PMA Nomor 9 Tahun 1965, untuk selanjutnya dalam penulisan ini disebut / ditulis "PMA Nomor 9 Tahun 1965," atau "PMA No. 9 Tahun 1965."

${ }^{24}$ Kementerian Negara Agraria/Kepala Badan Pertanahan Nasional, Peraturan Menteri Negara Agraria/Kepala Badan Pertanahan Nasional tentang Ketentuan Pelaksanaan Peraturan Pemerintah Nomor 24 Tahun 1997 tentang Pendaftaran Tanah, PMNA/Kepala BPN Nomor 3 Tahun 1997, untuk selanjutnya dalam penulisan ini disebut / ditulis "PMNA/Ka.BPN Nomor 3 Tahun 1997," atau "PMNA/Ka.BPN No. 3 Tahun 1997."

${ }^{25}$ Badan Pertanahan Nasional, Peraturan Kepala Badan Pertanahan Nasional tentang Perubahan Atas Peraturan Menteri Negara Agraria/Kepala Badan Pertanahan Nasional Nomor 3 Tahun 1997 tentang Ketentuan Pelaksanaan Peraturan Pemerintah Nomor 24 Tahun 1997 tentang Pendaftaran Tanah, Peraturan Kepala BPN Nomor 8 Tahun 2012, untuk selanjutnya dalam penulisan ini disebut / ditulis "Perka.BPN Nomor 8 Tahun 2012," atau "Perka.BPN No. 8 Tahun 2012."

${ }^{26}$ Kementerian Negara Agraria/Kepala Badan Pertanahan Nasional, Keputusan Menteri Negara Agraria/Kepala Badan Pertanahan Nasional tentang Perubahan Hak Milik Menjadi Hak Guna Bangunan atau Hak Pakai dan Hak Guna Bangunan Menjadi Hak Pakai, Kep.MNA/Kepala BPN Nomor 16 Tahun 1997, untuk selanjutnya dalam penulisan ini disebut / ditulis "Kep.MNA/Ka.BPN Nomor 
Hak Milik Menjadi Hak Guna Bangunan atau Hak Pakai dan Hak Guna Bangunan Menjadi Hak Pakai, Peraturan Menteri Negara Agraria/Kepala Badan Pertanahan Nasional Nomor 9 Tahun $1999^{27}$ Tentang Tata Cara Pemberian Dan Pembatalan Hak Atas Tanah Negara Dan Hak Pengelolaan, Peraturan Kepala Badan Pertanahan Nasional Nomor 1 Tahun $2006^{28}$ Tentang Ketentuan Pelaksanaan Peraturan Pemerintah Nomor 37 Tahun 1998 Tentang Peraturan Jabatan Pejabat Pembuat Akta Tanah sebagaimana diubah dengan Peraturan Kepala Badan Pertanahan Nasional Nomor 23 Tahun 2009. ${ }^{29}$

Berdirinya rumah susun (apartemen; condominium) diatas bidang tanah hak atas tanah tertentu tersebut berdasarkan asas pemisahan horizontal yang diatur dalam Pasal

16 Tahun 1997," atau "Kep.MNA/Ka.BPN No. 16 Tahun 1997."

${ }^{27}$ Kementerian Negara Agraria/Kepala Badan Pertanahan Nasional, Peraturan Menteri Negara Agraria/Kepala Badan Pertanahan Nasional tentang Tata Cara Pemberian Dan Pembatalan Hak Atas Tanah Negara Dan Hak Pengelolaan, PMNA/Kepala BPN Nomor 9 Tahun 1999, untuk selanjutnya dalam penulisan ini disebut / ditulis "PMNA/Ka.BPN Nomor 9 Tahun 1999," atau "PMNA/Ka.BPN No. 9 Tahun 1999."

${ }^{28}$ Badan Pertanahan Nasional, Peraturan Kepala Badan Pertanahan Nasional tentang Ketentuan Pelaksanaan Peraturan Pemerintah Nomor 37 Tahun 1998 Tentang Peraturan Jabatan Pejabat Pembuat Akta Tanah, Peraturan Kepala BPN Nomor 1 Tahun 2006, untuk selanjutnya dalam penulisan ini disebut / ditulis "Perka.BPN Nomor 1 Tahun 2006," atau "Perka.BPN No. 1 Tahun 2006."

${ }^{29}$ Badan Pertanahan Nasional, Peraturan Kepala Badan Pertanahan Nasional tentang Perubahan Atas Peraturan Kepala Badan Pertanahan Nasional Nomor 1 Tahun 2006 tentang Ketentuan Pelaksanaan Peraturan Pemerintah Nomor 37 Tahun 1998 Tentang Peraturan Jabatan Pejabat Pembuat Akta Tanah, Peraturan Kepala BPN Nomor 23 Tahun 2009, untuk selanjutnya dalam penulisan ini disebut / ditulis "Perka.BPN Nomor 23 Tahun 2009," atau "Perka.BPN No. 23 Tahun 2009."
44 ayat (1) UU No. 5 Tahun $1960 .{ }^{30}$ Asas pemisahan horizontal bermakna bahwa antara pemilih tanah dengan pemilik bangunan gedung dapat terpisah dan dipisahkan. sehingga pemilik bangunan gedung tidak selalu harus pemilik bidang tanah dimana bangunan tersebut berdiri.

Asas pemisahan horizontal, menurut Effendi Perangin, mengadung 2 (dua) segi yaitu : ${ }^{31}$

a. segi hukumnya, diadakan pemisahan antara hukum yang berlaku terhadap tanah dan hukum yang berlaku terhadap bangunan, dimana hukum yang berlaku terhadap tanah diatur dalam UU No. 5 Tahun 1960 beserta peraturan pelaksanaannya.

Sedangkan hukum yang berlaku terhadap bangunan diatur dalam Undang-Undang Nomor 28 Tahun 2002 Tentang Bangunan Gedung, ${ }^{32} \quad$ Undang-Undang Nomor 2 Tahun 2017 Tentang Jasa Konstruksi, ${ }^{33}$ beserta segenap aturan pelaksanaannya.

${ }^{30}$ UU No. 5 Tahun 1960, Pasal 44 "Seorang atau suatu badan hukum mempunyai hak sewa atas tanah, apabila ia berhak menggunakan tanah milik orang lain untuk keperluan bangunan, dengan membayar kepada pemiliknya, sejumlah uang sebagai uang sewa."

${ }^{31}$ Effendi Perangin, Hukum Agraria Indonesia: Suatu Telaah Sudut Pandang Praktisi Hukum, (Jakarta : Rajawali, 1986), hlm. 92-94.

${ }^{32}$ Indonesia, Undang-Undang Tentang Bangunan Gedung, UU Nomor 28 Tahun 2002, Lembaran Negara Republik Indonesia Tahun 2002 Nomor 134, Tambahan Lembaran Negara Republik Indonesia Nomor 4247), untuk selanjutnya dalam penulisan ini disebut / ditulis "UU Nomor 28 Tahun 2002."

${ }^{33}$ Indonesia, Undang-Undang Tentang Jasa Konstruksi, UU Nomor 2 Tahun 2017, Lembaran 


\section{b. segi pemilikan bangunannya}

Pemilikan tanah tidak dengan sendirinya meliputi pemilikan bangunan yang ada diatas bidang tanah yang bersangkutan, jika bangunan tersebut didirikan oleh orang lain, siapa yang membangun dialah pemilik bangunan tersebut, kecuali kalau ada perjanjian lain.

Untuk dapat memahami rumah susun terlebih dahulu harus memahami istilah-istilah umum berlaku dalam berkenaan dengan rumah susun yaitu Satuan rumah susun atau sarusun atau $\mathrm{SRS},{ }^{34}$ Tanah bersama, ${ }^{35}$ Bagian bersama, ${ }^{36}$ Benda bersama, ${ }^{37}$ Rumah susun umum, ${ }^{38}$ Rumah susun khusus, ${ }^{39}$

Negara Republik Indonesia Tahun 2017 Nomor 111, Tambahan Lembaran Negara Republik Indonesia Nomor 6018), untuk selanjutnya dalam penulisan ini disebut / ditulis "UU Nomor 2 Tahun 2017."

${ }^{34}$ UU No. 20 Tahun 2011 Pasal 1 angka 3

"Satuan rumah susun yang selanjutnya disebut sarusun adalah unit rumah susun yang tujuan utamanya digunakan secara terpisah dengan fungsi utama sebagai tempat hunian dan mempunyai sarana penghubung ke jalan umum."

${ }^{35}$ UU No. 20 Tahun 2011 Pasal 1 angka 4 "Tanah bersama adalah sebidang tanah hak atau tanah sewa untuk bangunan yang digunakan atas dasar hak bersama secara tidak terpisah yang di atasnya berdiri rumah susun dan ditetapkan batasnya dalam persyaratan izin mendirikan bangunan."

${ }^{36}$ UU No. 20 Tahun 2011 Pasal 1 angka 5 "Bagian bersama adalah bagian rumah susun yang dimiliki secara tidak terpisah untuk pemakaian bersama dalam kesatuan fungsi dengan satuan-satuan rumah susun."

${ }^{37}$ UU No. 20 Tahun 2011 Pasal 1 angka 6 "Benda bersama adalah benda yang bukan merupakan bagian rumah susun melainkan bagian yang dimiliki bersama secara tidak terpisah untuk pemakaian bersama."

${ }^{38}$ UU No. 20 Tahun 2011 Pasal 1 angka 7 "Rumah susun umum adalah rumah susun yang
Rumah susun negara, ${ }^{40}$ Rumah susun komersial, ${ }^{41}$ Sertifikat hak milik sarusun atau SHM sarusun atau SHMSRS, ${ }^{42}$ SKBG sarusun atau SKBG SRS, ${ }^{43}$ Nilai perbandingan proporsional (NPP), ${ }^{44}$ Masyarakat berpenghasilan rendah $(\mathrm{MBR}){ }^{45}$

diselenggarakan untuk memenuhi kebutuhan rumah bagi masyarakat berpenghasilan rendah."

${ }^{39}$ UU No. 20 Tahun 2011 Pasal 1 angka 8 "Rumah susun khusus adalah rumah susun yang diselenggarakan untuk memenuhi kebutuhan khusus."

${ }^{40}$ UU No. 20 Tahun 2011 Pasal 1 angka 9 "Rumah susun negara adalah rumah susun yang dimiliki negara dan berfungsi sebagai tempat tinggal atau hunian, sarana pembinaan keluarga, serta penunjang pelaksanaan tugas pejabat dan/atau pegawai negeri."

${ }^{41}$ UU No. 20 Tahun 2011 Pasal 1 angka 10 "Rumah susun komersial adalah rumah susun yang diselenggarakan untuk mendapatkan keuntungan."

${ }^{42}$ UU No. 20 Tahun 2011 Pasal 1 angka 11 "Sertifikat hak milik sarusun yang selanjutnya disebut SHM sarusun adalah tanda bukti kepemilikan atas sarusun di atas tanah hak milik, hak guna bangunan atau hak pakai di atas tanah negara, serta hak guna bangunan atau hak pakai di atas tanah hak pengelolaan."

${ }^{43}$ UU No. 20 Tahun 2011 Pasal 1 angka 12 "Sertifikat kepemilikan bangunan gedung sarusun yang selanjutnya disebut SKBG sarusun adalah tanda bukti kepemilikan atas sarusun di atas barang milik negara/daerah berupa tanah atau tanah wakaf dengan cara sewa."

${ }^{44}$ UU No. 20 Tahun 2011 Pasal 1 angka 13 "Nilai perbandingan proporsional yang selanjutnya disebut NPP adalah angka yang menunjukkan perbandingan antara sarusun terhadap hak atas bagian bersama, benda bersama, dan tanah bersama yang dihitung berdasarkan nilai sarusun yang bersangkutan terhadap jumlah nilai rumah susun secara keseluruhan pada waktu pelaku pembangunan pertama kali memperhitungkan biaya pembangunannya secara keseluruhan untuk menentukan harga jualnya."

${ }^{45}$ UU No. 20 Tahun 2011 Pasal 1 angka 14 "Masyarakat berpenghasilan rendah yang selanjutnya disebut MBR adalah masyarakat yang mempunyai keterbatasan daya beli sehingga perlu mendapat dukungan pemerintah untuk memperoleh sarusun umum." 
Pelaku pembangunan rumah susun (pelaku pembangunan), ${ }^{46}$ Setiap orang, ${ }^{47}$ Badan hukum, ${ }^{48}$ Pemilik, ${ }^{49}$ Penghuni, ${ }^{50} \quad$ Pengelola, ${ }^{51}$ Perhimpunan pemilik dan penghuni sarusun (PPPSRS), ${ }^{52}$ Pemerintah pusat (Pemerintah), ${ }^{53}$ Pemerintah daerah $(\text { Pemda })^{54}$ dan Menteri, ${ }^{55}$

${ }^{46}$ UU No. 20 Tahun 2011 Pasal 1 angka 15 "Pelaku pembangunan rumah susun yang selanjutnya disebut pelaku pembangunan adalah setiap orang dan/atau pemerintah yang melakukan pembangunan perumahan dan permukiman."

${ }^{47}$ UU No. 20 Tahun 2011 Pasal 1 angka 16 "Setiap orang adalah orang perseorangan atau badan hukum."

${ }^{48}$ UU No. 20 Tahun 2011 Pasal 1 angka 17 "Badan hukum adalah badan hukum yang didirikan oleh warga negara Indonesia yang kegiatannya di bidang penyelenggaraan perumahan dan kawasan permukiman."

${ }^{49}$ UU No. 20 Tahun 2011 Pasal 1 angka 18 "Pemilik adalah setiap orang yang memiliki sarusun."

${ }^{50}$ UU No. 20 Tahun 2011 Pasal 1 angka 19 "Penghuni adalah orang yang menempati sarusun, baik sebagai pemilik maupun bukan pemilik."

${ }^{51}$ UU No. 20 Tahun 2011 Pasal 1 angka 20 "Pengelola adalah suatu badan hukum yang bertugas untuk mengelola rumah susun."

${ }^{52}$ UU No. 20 Tahun 2011 Pasal 1 angka 21 "Perhimpunan pemilik dan penghuni sarusun yang selanjutnya disebut PPPSRS adalah badan hukum yang beranggotakan para pemilik atau penghuni sarusun."

${ }^{53}$ UU No. 20 Tahun 2011 Pasal 1 angka 22 "Pemerintah pusat yang selanjutnya disebut Pemerintah adalah Presiden Republik Indonesia yang memegang kekuasaan pemerintahan negara Republik Indonesia sebagaimana dimaksud dalam Undang-Undang Dasar Negara Republik Indonesia Tahun 1945."

${ }^{54}$ UU No. 20 Tahun 2011 Pasal 1 angka 23 "Pemerintah daerah adalah gubernur, bupati atau walikota, dan perangkat daerah sebagai unsur penyelenggara pemerintahan daerah."

${ }^{55}$ UU No. 20 Tahun 2011 Pasal 1 angka 24 "Menteri adalah menteri yang menyelenggarakan urusan pemerintahan di bidang perumahan dan kawasan semuanya diatur dalam UU No. 20 Tahun 2011.

Rumah susun (apartemen, condominium), berdasarkan ketentuan Pasal 17 UU No. 20 Tahun 2011, dapat dibangun di atas tanah hak milik $^{56}$ (HM), hak Guna Bangunan ${ }^{57}$ (HGB) atau hak Pakai (HP) atas Tanah Negara ${ }^{58}$ (TN), dan hak Guna Bangunan (HGB) atau Hak Pakai (HP) di atas hak Pengelolaan ${ }^{59}$ (HPl).

permukiman."

${ }^{56}$ Hak Milik (HM), Pengertian HM diatur dalam Pasal 20 ayat (1) UU No. 5 Tahun 1960, Subjek HM diatur dalam Pasal 21 UU PA Jo. PP No. 38 Tahun 1963, Peralihan HM diatur dalam Pasal 20 ayat (2) UU No. 5 Tahun 1960 Jo. Pasal 37 s/d Pasal 42 PP No. 24/1997 Jo. Pasal 107 s/d Pasal 112 PMNA/Ka.BPN No. 3/1997, terjadinya HM Pasal 22, Pasal I, II dan IV ayat (1) UU No. 5 Tahun 1960 Jo. Pasal 8 s/d Pasal 16 PMNA/Ka.BPN No. 9 Tahun 1999.

${ }^{57}$ Hak Guna Bangunan (HGB), Pengaturan HGB diatur dalam Pasal 16 ayat (1) huruf c Jo. Pasal 35 s/d Pasal 40 Jo. Pasal 50 ayat (2) UU No. 5 Tahun 1960; Pasal 19 s/d Pasal 38 PP No. 40 Tahun 1996 ; Pasal 4, Pasal 9 dan Pasal 14 PMNA/Ka.BPN No. 3 Tahun 1999 sebagaimana diubah menjadi Pasal 4, Pasal 8 dan Pasal 11 Perka.BPN No. 1 Tahun 2011 Jis Pasal 32 s/d Pasal 48 PMNA/Ka.BPN No. 9 Tahun 1999. Sedangkan Bentuk Akta Pemberian HGB atas Tanah HM diatur dalam Lampiran PMNA/Ka.BPN No. 3/1997 Jis. PP No. 37 Tahun 1998 dan Perka.BPN No. 1 Tahun 2006.

${ }^{58}$ Hak Pakai (HP), Pengaturan HP diatur dalam Pasal 16 ayat (1) huruf d Jo. Pasal $41 \mathrm{~s} / \mathrm{d}$ Pasal 43 Jo. Pasal 50 ayat (2) UU No. 5 Tahun 1960; Pasal 39 s/d Pasal 58 PP No. 40 Tahun 1996 ; Pasal 5 PMNA/Ka.BPN No. 3 Tahun 1999 sebagaimana diubah menjadi Pasal 5, Pasal 9 dan Pasal 11 Perka.BPN No. 1 Tahun 2011 Jis Pasal 50 s/d Pasal 56 PMNA/Ka.BPN No. 9 Tahun 1999. Sedangkan Bentuk Akta Pemberian HP atas Tanah HM diatur dalam Lampiran PMNA/Ka.BPN No. 3 Tahun 1997 Jis. PP No. 37 Tahun 1998 dan Perka.BPN No. 1 tahun 2006.

${ }^{59}$ Hak Pengelolaan (HP1), Pengaturan HP1 Pasal 16 ayat (1) huruf h UU No. 5 Tahun 1960; PMA No. 9 Tahun 1965 ; Pasal 1 angka2 PP No. 40/1996 ; Pasal 9 PP No. 24/1997; Pasal 1 angka 1 PMNA/Ka.BPN No. 3 tahun 1999 ; Pasal 67 s/d Pasal 75 PMNA/Ka.BPN No. 9 Tahun 1999. 
2. Orang Asing / Warga Negara Asing Di Indonesia

Apabila dicermati UndangUndang Nomor 12 Tahun 2006 Tentang Kewarganegaraan Republik Indonesia $^{60}$ tidak diketemukan definisi atau pengertian warga negara Asing ataupun orang asing yang berada di Indonesia.

Ketentuan yang diatur dalam Pasal $4^{61}$ UU No. 12 Tahun 2006

${ }^{60}$ Indonesia, Undang-Undang Tentang Kewarganegaraan, UU Nomor 12 Tahun 2006, Lembaran Negara Republik Indonesia Tahun 2006 Nomor 63, Tambahan Lembaran Negara Republik Indonesia Nomor 4634), untuk selanjutnya dalam penulisan ini disebut / ditulis "UU No. 12 Tahun 2006," atau "UU Kewarganegaraan."

${ }^{61}$ UU No. 12 Tahun 2006 Pasal 4 "Warga Negara Indonesia adalah:

a. setiap orang yang berdasarkan peraturan perundang-undangan dan/atau berdasarkan perjanjian Pemerintah Republik Indonesia dengan negara lain sebelum Undang-Undang ini berlaku sudah menjadi Warga Negara Indonesia;

b. anak yang lahir dari perkawinan yang sah dari seorang ayah dan ibu Warga Negara Indonesia;

c. anak yang lahir dari perkawinan yang sah dari seorang ayah Warga Negara Indonesia dan ibu warga negara asing;

d. anak yang lahir dari perkawinan yang sah dari seorang ayah warga negara asing dan ibu Warga Negara Indonesia.

e. anak yang lahir dari perkawinan yang sah dari seorang ibu Warga Negara Indonesia, tetapi ayahnya tidak mempunyai kewarganegaraan atau hukum negara asal ayahnya tidak memberikan kewarganegaraan kepada anak tersebut;

f. anak yang lahir dalam tenggang waktu 300 (tiga ratus) hari setelah ayahnya meninggal dunia dari perkawinan yang sah dan ayahnya Warga Negara Indonesia;

g. anak yang lahir di luar perkawinan yang sah dari seorang ibu Warga Negara Indonesia;

h. anak yang lahir di luar perkawinan yang sah dari seorang ibu warga negara asing yang diakui oleh seorang ayah Warga Negara Indonesia sebagai anaknya dan pengakuan itu dilakukan sebelum anak tersebut berusia 18 (delapan belas) tahun dan/atau belum kawin;

i. anak yang lahir di wilayah negara Republik adalah kriteria dan ruang lingkup Warga Negara Indonesia, sehingga dengan pendekatan a contra rio atas ketentuan Pasal 4 UU No. 12 Tahun 2006 tersebut, dapat dimaknai bahwa warga negara Asing yang berada di Indonesia adalah orang / warga negara yang tidak memenuhi kriteria yang diatur dalam Pasal 4 UU No. 12 Tahun 2006.

Pengertian orang asing adalah orang bukan Warga Negara Indonesia, sebagaimana diatur dalam Pasal 1 angka 4 UndangUndang Nomor 23 Tahun 2006 tentang Administrasi Kependudukan $^{62} \quad$ sebagaimana diubah dengan Undang-Undang Nomor 24 Tahun 2013 Tentang Perubahan Atas Undang-Undang Nomor 23 Tahun 2006 Tentang

Indonesia yang pada waktu lahir tidak jelas status kewarganegaraan ayah dan ibunya;

j. $\quad$ anak yang baru lahir yang ditemukan di wilayah negara Republik Indonesia selama ayah dan ibunya tidak diketahui;

k. anak yang lahir di wilayah negara Republik Indonesia apabila ayah dan ibunya tidak mempunyai kewarganegaraan atau tidak diketahui keberadaannya.

1. anak yang dilahirkan di luar wilayah negara Republik Indonesia dari seorang ayah dan ibu Warga Negara Indonesia yang karena ketentuan dari negara tempat anak tersebut dilahirkan memberikan kewarganegaraan kepada anak yang bersangkutan;

m. anak dari seorang ayah atau ibu yang telah dikabulkan permohonan kewarganegaraannya, kemudian ayah atau ibunya meninggal dunia sebelum mengucapkan sumpah atau menyatakan janji setia."

${ }^{62}$ Indonesia, Undang-Undang Tentang Administrasi Kependudukan, UU Nomor 23 Tahun 2006, Lembaran Negara Republik Indonesia Tahun 2006 Nomor 124, Tambahan Lembaran Negara Republik Indonesia Nomor 4674), untuk selanjutnya dalam penulisan ini disebut / ditulis "UU No. 23 Tahun 2006," atau "UU Administrasi Kependudukan." 
Tinjauan Hukum Pemilikan Apartemen (Satuan Rumah Susun)

Oleh Orang Asing / Warga Negara Asing Di Indonesia

Administrasi Kependudukan. ${ }^{63}$

Orang asing yang berkedudukan di Indonesia yang dapat memiliki Rumah Tempat Tinggal atau Hunian termasuk rumah susun (apartemen) di Indonesia adalah orang yang keberadaanya memberikan manfaat, melakukan usaha, bekerja, atau berinvestasi di Indonesia, sebagaimana dinyatakan dalam Pasal 1 angka 1 PP No. 103 Tahun $2015 .^{64}$

\section{E. Metode Penelitian}

Penelitian $^{65}$ ini merupakan penelitian hukum atau kajian hukum, ${ }^{66}$ oleh

\footnotetext{
${ }^{63}$ Indonesia, Undang-Undang Tentang Perubahan Atas Undang-Undang Nomor 23 Tahun 2006 Tentang Administrasi Kependudukan, UU Nomor 24 Tahun 2013, Lembaran Negara Republik Indonesia Tahun 2013 Nomor 232, Tambahan Lembaran Negara Republik Indonesia Nomor 5475), untuk selanjutnya dalam penulisan ini disebut / ditulis "UU No. 24 Tahun 2013," atau "UU Perubahan Administrasi Kependudukan."
}

${ }^{64}$ PP No. 103 Tahun 2015 Pasal 1 angka 1 "Orang Asing yang Berkedudukan di Indonesia yang selanjutnya disebut Orang Asing adalah orang yang bukan Warga Negara Indonesia yang keberadaanya memberikan manfaat, melakukan usaha, bekerja, atau berinvestasi di Indonesia."

${ }^{65}$ Penelitian (research) merupakan upaya pencarian kembali yang amat bernilai edukatif disebabkan oleh hasrat ingin tahu dari manusia yang dipertanyakannya. Lihat Amirudin dan Zainal Asikin, Pengantar Metode Penelitian Hukum, Ed. 1, Cet. 3, (Jakarta: PT Raja Grafindo Persada, 2006), hlm 19. Penelitian merupakan suatu sarana pokok dalam pengembangan ilmu pengetahuan dan teknologi, oleh karena penelitian bertujuan untuk mengungkapkan kebenaran secara sistematis, metodologis dan konsisten, dengan mengadakan analisa dan konstruksi. Lihat juga: Soerjono Soekanto dan Sri Mamudji, Penelitian Hukum Normatif Suatu Tinjauan Singkat, Ed. 1, Cet. 5, (Jakarta : PT. RajaGrafindo Persada, 2001), hlm. 20. ${ }^{66}$ Kajian hukum berarti menggunakan disiplin hukum. Disiplin hukum, menurut Soerjono Soekanto dan Sri Mamudji, adalah suatu sistem ajaran tentang hukum sebagai norma dan sebagai kenyataan (= perilaku atau sikap tindak. Artinya, karenanya metode ${ }^{67}$ penelitian $^{68}$ yang dipilih dan dipergunakan adalah metode penelitian hukum yaitu metode penelitian hukum normatif (penelitian yuridis normatif) ${ }^{69}$ atau penelitian

disiplin hukum menyoroti hukum sebagai sesuatu yang dicita-citakan, maupun sebagai suatu realitas. Lihat: Soerjono Soekanto dan Sri Mamudji, Op.Cit., hlm. 2.

${ }^{67}$ Metode, secara etimologis berasal dari bahasa Yunani, yakni kata "methodos, yang berarti "cara atau jalan," sedangkan metodologi, yaitu pengetahuan tentang berbagai cara kerja yang disesuaikan dengan objek studi (penelitian) ilmu yang bersangkutan. Lihat Fuad Hasan dan Koentjaraningrat, "Beberapa Azas Metodologi Ilmiah," dalam Koentjaraningrat (Ed.), Metode-metode Penelitian Masyarakat, Cet. 9, Jakarta: PT. Gramedia Jakarta, 1989, hlm. 7 - 8. Sementara itu, metode penelitian adalah cara atau jalan atau proses pemeriksaan atau penyelidikan yang menggunakan cara penalaran dan berpikir yang logisanalitis (logika), berdasarkan dalil-dalil, rumus-rumus dan teori-teori suatu ilmu (atau beberapa cabang ilmu) tertentu, untuk menguji kebenaran (atau mengadakan verifikasi) suatu hipotesis atau teori tentang gejala-gejala atau peristiwa alamiah, peristiwa sosial atau peristiwa hukum tertentu. Lihat pula C. F. G. Sunarjati Hartono, Penelitian Hukum Di Indonesia Pada Akhir Abad Ke-20, Cet. 1, (Bandung : Alumni, 1994), hlm. 10.

${ }^{68}$ Metode penelitian adalah suatu cara atau jalan untuk memperoleh kembali pemecahan terhadap segala permasalahan dengan menerapkan salah satu metode yang relevan terhadap permasalahan tersebut. Lihat. Joko Subagyo, Metode Penelitian Dalam Teori Dan Praktek, (Jakarta : Rineka Cipta, 2004), hlm. 2

${ }^{69}$ Penelitian hukum normatif atau penelitian hukum kepustakaan adalah penelitian hukum yang dilakukan dengan cara meneliti bahan pustaka atau data sekunder belaka. Penelitian hukum normatif atau penelitian hukum kepustakaan tersebut mencakup penelitian terhadap asas-asas hukum dan penelitian terhadap taraf sinkronisasi vertikal dan horizontal. Lihat: Soerjono Soekanto dan Sri Mamudji, Op.Cit., hlm. 13-14. Nama lain dari penelitian hukum normatif adalah penelitian hukum doktriner, juga disebut sebagai penelitian perpustakaan atau studi dokumen atau studi kepustakaan. Disebut penelitian hukum doktriner, karena penelitian ini dilakukan atau ditujukan hanya pada peraturanperaturan yang tertulis atau bahan-bahan hukum yang lain. Sebagai penelitian perpustakaan ataupun studi dokumen disebabkan penelitian ini lebih banyak dilakukan terhadap data yang bersifat sekunder yang ada di perpustakaan. Lihat pula Bambang Waluyo, Penelitian Hukum Dalam Praktek, Ed. 1, Cet. 2, (Jakarta : Sinar Grafika, 1996), hlm. 13-14. Penelitian hukum normatif menggunakan studi kasus hukum normatif berupa produk perilaku 
hukum doktrinal (doctrinal research) atau penelitian hukum kepustakaan (library research) ${ }^{71}$ dengan cara meneliti bahan pustaka.

Kemudian pendekatan penelitian
hukum $^{72}$ yang digunakan dalam

hukum, misalnya mengkaji suatu undang-undang. Pokok kajiannya adalah hukum yang dikonsepsikan sebagai norma atau kaidah yang berlaku dalam masyarakat dan menjadi acuan perilaku setiap orang. Lihat juga: Abdulkadir Muhammad, Hukum dan Penelitian Hukum, Cet. 1, (Bandung : PT. Citra Aditya Bakti, 2004), hlm. 52.

${ }^{70}$ Penelitian hukum doktrinal, menurut Soetandyo Wighjosoebroto sebagaimana dikutip oleh Bambang Sunggono, terdiri dari (1) penelitian yang berupa usaha inventarisasi hukum positif, (2) penelitian yang berupa usaha penemuan asas dan dasar falsafah (dogma atau doktrin) hukum positif, (3) penelitian yang berupa usaha penemuan hukum in concreto yang layak diterapkan untuk menyelesaikan suatu perkara hukum tertentu. Lihat Bambang Sunggono, Metodologi Penelitian Hukum (Suatu Pengantar), Ed. 1., Cet. 3, (Jakarta: PT. Raja Grafindo Persada, 2001), hlm. 43.

${ }^{71}$ Ronny Hanitijo Soemitro, Metodologi Penelitian Hukum Dan Jurimetri, Cet. ke-3, (Jakarta: Ghalia Indonesia, 1988), hlm. 9.

${ }^{72}$ Dengan pendekatan penelitian hukum, peneliti akan mendapatkan informasi dari berbagai aspek mengenai isu yang sedang dicoba untuk dicari jawabannya. Pendekatan-pendekatan yang digunakan di dalam penelitian hukum adalah 1 . pendekatan undang-undang (statute approach), 2. pendekatan kasus (case approach), 3. pendekatan historis (historical approach), 4. pendekatan komparatif (comparative approach), dan 5. pendekatan konseptual (conceptual approach). Lihat Peter Mahmud Marzuki, Penelitian Hukum, Ed. Revisi, Cet. 8, Jakarta : Kencana, Prenada Media Grup, 2013, hlm. 133. Cara pendekatan (approach) yang digunakan dalam suatu penelitian normatif akan memungkinkan seorang peneliti untuk memanfaatkan hasil-hasil temuan ilmu hukum empiris dan ilmu-ilmu lain untuk kepentingan dan analisis serta eksplanasi hukum tanpa mengubah karakter ilmu hukum sebagai ilmu normatif. Berbagai bahan hukum banyak yang memiliki sifat empiris seperti perbandingan hukum, sejarah hukum, dan kasus-kasus hukum yang telah diputus. Sebagaimana telah dibahas sebelumnya bahwa ilmu hukum normatif dapat dan harus memanfaatkan berbagai temuan ilmu lain, serta berinteraksi secara positif dengan ilmu-ilmu lain, khususnya ilmu hukum empiris. Dalam kaitannya dengan penelitian normatif dapat digunakan beberapa pendekatan berikut: 1. Pendekatan Perundang-undangan (statute approach); 2. Pendekatan Konsep (conceptual approach); 3. Pendekatan Analitis (analytical penelitian ini adalah statute approach (pendekatan undang-undang) dengan menelaah berbagai peraturan perundang-undangan regulasi yang berkaitan dengan pengaturan pemilikan satuan unit rumah susun (apartemen) oleh orang Asing/warga negara Asing. ${ }^{73}$ Disamping itu, menelaah

approach); 4. Pendekatan Perbandingan (comparative approach); 5. Pendekatan Historis (historical approach); 6. Pendekatan Filsafat (philosophical approach); 7. Pendekatan Kasus (case approach). Cara pendekatan tersebut dapat digabung sehingga dalam suatu penelitian hukum normatif dapat saja menggunakan dua pendekatan atau lebih yang sesuai, misalnya pendekatan perundang-undangan, pendekatan historis, dan pendekatan perbandingan. Lihat pula Jhonny Ibrahim, Teori Dan Metodologi Penelitian Hukum Normatif, Ed. Revisi, Cet.3., \{Malang: Bayumedia Publishing, 2007, hlm. 300 - 301.

${ }^{73}$ Pendekatan undang-undang (statute approach) dilakukan dengan menelaah semua undang-undang dan regulasi yang bersangkut paut dengan isu hukum yang sedang ditangani. Bagi penelitian untuk kegiatan praktis, pendekatan undang-undang ini akan membuka kesempatanbagi peneliti untuk mempelajari adakah konsistensi dan kesesuaian antara suatu undang-undang dengan undang-undang lainnya atau antara undang-undang dan Undang-Undang Dasar atau antara regulasi dan undang-undang. Hasil dari telaah tersebut merupakan suatu argumen untuk memecahkan isu yang dihadapi. Bagi penelitian untuk kegiatan akademis, peneliti perlu mencari ratio legis dan dasar ontologis lahirnya undang-undang tersebut. Dengan mempelajari ratio legis dan dasar ontologis suatu undang-undang, peneliti sebenarnya mampu menangkap kandungan filosofi yang ada di belakang undang-undang. itu. Memahami kandungan filosofi yang ada di belakang undang-undang itu, peneliti tersebut akan dapat menyimpulkan mengenai ada tidaknya benturan filosofis antara undang-undang dengan isu yang dihadapi. Lihat Peter Mahmud Marzuki, Op.Cit., hlm. 133-134. Suatu penelitian normatif tentu harus menggunakan pendekatan perundang-undangan, karena yang akan diteliti adalah berbagai aturan hukum yang menjadi fokus sekaligus tema sentral suatu penelitian. Lihat pula Jhonny Ibrahim, Op.Cit., hlm. 302 
hubungan dan konsistensi pengaturan pemilikan satuan unit rumah susun (apartemen) oleh orang Asing/warga negara Asing di Indonesia.

Data $^{74}$ yang digunakan dalam penelitian ini adalah data sekunder ${ }^{75}$ yang diperoleh dari bahan hukum berupa Pertama, bahan hukum primer yang meliputi UU No. 5 Tahun 1960 , UU No. 16 Tahun 1985, UU No. 23 Tahun 2006, 2006, UU No. 1 Tahun 2011, UU No. 20 Tahun 2011, UU No. 24 Tahun 2013, PP No. 4 Tahun 1988, PP No. 40 Tahun 1996, PP No. 41 Tahun 1996, PP No. 24 Tahun 1997, PP No. 37 Tahun 1998, PP No. 103 Tahun 2015, PP No. 24 Tahun 2016. Kedua, bahan hukum sekunder yang meliputi pelaksanaan teknis dari UndangUndang dan Peraturan Pemerintah tersebut diatas yaitu PMA No. 9 Tahun 1965, PMNA/Ka.BPN No. 7 Tahun 1996, PMNA/Ka.BPN No. 3 Tahun 1997, Kep.MNA/Ka.BPN No. 16

${ }^{74}$ Data, secara etimologis berasal dari bahasa Latin, dengan akar kata "do" yang artinya memberi; menunjukkan; menganugerahkan; menyerahkan. "data" adalah bentuk Jamak (Plural) dari "datum" yang Tunggal (Singular). Lihat Peter Mahmud Marzuki, Op.Cit., hlm. 59, dalam Catatan Kaki Nomor 8.

${ }^{75}$ Menurut tempat diperolehnya, data dalam penelitian dibedakan antara data primer dan data sekunder. Data primer adalah data yang diperoleh langsung dari masyarakat, sedangkan data sekunder adalah data yang diperoleh dari kepustakaan. Lihat Sri Mamudji, Et.al, Metode Penelitian Dan Penulisan Hukum, Cet. 1, Depok: Badan Penerbit FH UI, 2005, hlm. 6. Adapun data sekunder tersebut memiliki ciri-ciri umum sebagai berikut: 1) data sekunder pada umumnya ada dalam keadaan siap terbuat (ready made); 2) bentuk maupun isi data sekunder telah dibentuk dan diisi oleh peneliti-peneliti terdahulu.; 3) data sekunder dapat diperoleh tanpa terikat atau dibatasi oleh waktu dan tempat. Dengan adanya data sekunder tersebut, seorang peneliti tidak perlu mengadakan penelitian sendiri dan secara langsung terhadap faktor-faktor yang menjadi latar belakang penelitiannya sendiri. Lihat pula: Soerjono Soekanto dan Sri Mamudji, Op.Cit., hlm. 24.
Tahun 1997, PMNA/Ka.BPN No. 9 Tahun 1999, Perka.BPN No. 1 Tahun 2006, Permen ATR/Ka.BPN No. 13 Tahun 2016, Permen ATR/Ka.BPN No. 29 Tahun 2016 serta termasuk pula literatur berupa kajian-kajian para ahli hukum berkenaan dengan Pemilikan rumah susun (apartemen, condominium) oleh warga negara Asing pada khususnya, dan lainnya yang memiliki hubungan dengan pembahasan makalah ini. Ketiga, bahan hukum tersier yang berupa ensiklopedia dan kamus-kamus.

Bahan-bahan hukum yang telah terkumpul kemudian diolah dan dianalisis dengan menggunakan metode penafsiran hukum dan metode konstruksi hukum.

Seluruh data yang berhasil dikumpulkan kemudian disortir dan diklasifikasikan, kemudian disusun melalui susunan yang komprehensif. Proses analisis diawali dari premispremis yang berupa norma hukum positif yang diketahui dan berakhir pada analisis dengan menggunakan asas-asas hukum, doktrin-doktrin serta teori-teori.

Metode analisis data yang dipergunakan dalam penelitian ini adalah metode analisis kualitatif, dengan meneliti data yang diperoleh secara mendalam dari berbagai segi, ${ }^{76}$ tidak selalu ditentukan oleh jumlah (kuantitas) peristiwa yang terjadi, dan tidak menggunakan konsep-konsep yang

${ }^{76}$ Norman K. Denzin \& Yvona S. Lincoln, ed. Handbook of Qualitative Research dikutip dari Natasya Yunita Sugiastuti, Tradisi Hukum Cina: Negara Dan Masyarakat (Studi Mengenai Peristiwaperistiwa Hukum di Pulau Jawa Zaman Kolonial (1870 1942), Cet. 1, Jakarta: Program Pasca Sarjana Fakultas Hukum Universitas Indonesia, 2003, hlm. 19. 
diukur atau dinyatakan dengan angka atau rumusan statistik, tetapi lebih menekankan proses daripada hasil atau produk. ${ }^{77}$ Dalam menganalisis data sekunder tersebut, penguraiaan data disajikan dalam bentuk kalimat yang konsisten, logis dan efektif serta sistematis sehingga memudahkan untuk interpretasi data dan kontruksi data serta pemahaman akan analisis yang dihasilkan. Pengolahan data pada hakikatnya merupakan kegiatan untuk mengadakan sistematisasi $^{78}$ terhadap bahan-bahan hukum.

Hasil penelitian ini bersifat deskriptif analitis yaitu memaparkan, atau mengambarkan peraturan hukum yang berlaku dikaitkan dengan teori-teori hukum dan praktek pelaksanaan hukum positif. Deskripsi yang diberikan dalam penelitian ini adalah gambaran secara menyeluruh dan sistematis mengenai pengaturan Pemilikan rumah susun (apartemen, condominium) oleh warga negara Asing. Sedangkan dikatakan analitis, karena akan dilakukan analisis terhadap berbagai aspek hukum yang mengatur tentang Pemilikan rumah susun (apartemen, condominium) oleh warga negara Asing.

Akhirnya sebagai cara untuk menarik kesimpulan dari hasil penelitian yang sudah terkumpul, digunakan metode berfikir deduktif. ${ }^{79}$

${ }^{77}$ John W. Creswell. Research Design of Qualitative \& Quantitative Approches, dalam Natasya Yunita Sugiastuti, Ibid.

${ }^{78}$ Sistematisasi berarti membuat klasifikasi terhadap bahan-bahan hukum tersebut untuk memudahkan pekerjaan analisis dan konstruksi. Soerjono Soekanto (1), Pengantar Penelitian Hukum, Cet. 3, Jakarta: UI Press, 1986, hlm. 251-252.

${ }^{79}$ Metode berpikir deduktif, yaitu pengambilan kesimpulan dari pernyataan yang bersifat umum ke suatu pernyataan yang bersifat khusus. Lihat: Winarno Surakhmad, Pengantar
Dengan menggunakan metode deduktif akan selalu menempatkan kaidah hukum dalam peraturan perundangan, prinsip-prinsip hukum, dan ajaran atau doktrin hukum sebagai premis mayor dan fakta atau peristiwa hukum sebagai premis minor yang dirangkai secara sistematis sebagai susunan fakta-fakta hukum untuk memberikan gambaran tentang Pemilikan rumah susun (apartemen, condominium) oleh warga negara Asing. ${ }^{80}$

\section{F. Hasil Dan Pembahasan}

\section{a. Pengaturan Pemilikan rumah susun (apartemen, condominium) oleh orang / warga negara Asing}

Pengaturan Pemilikan rumah susun (apartemen, condominium) oleh orang / warga negara Asing diawali dengan adanya PP No. 41 Tahun 1996, yang memuat dan terdiri dari 8 (delapan) Pasal.

Apabila dicermati secara PP No. 41 Tahun 1996 diperoleh beberapa fakta hukum sebagai berikut:

1. Landasan sosiologis yang melatarbelakangi diterbitkan PP No. 41 Tahun 1996 ini pada pokoknya adalah sebagai berikut: ${ }^{81}$

"a. bahwa untuk lebih memberikan kepastian hukum mengenai kemungkinan pemilikan tempat tinggal atau hunian oleh orang asing, diperlukan upaya penjabaran ketentuan dalam Undang-Undang Nomor 16 Tahun 1985 tentang

Penelitian Ilmiah, Dasar Metode dan Teknik, Ed. 7, (Bandung: Tarsito, 1984), hlm. 134.

${ }^{80}$ Peter Mahmud Marzuki, Op.Cit, hlm. 8394

${ }^{81}$ bagian "Menimbang," PP No. 41 Tahun 1996 
Rumah Susun, dan Undang-

Undang Nomor 4 Tahun 1992

tentang Perumahan dan

Permukiman;

b. bahwa berdasarkan ketentuan

Undang-Undang Nomor 16 Tahun

1985 tentang Rumah Susun dan

Undang-Undang Nomor 4 Tahun

1992 tentang Perumahan dan

Permukiman, kemungkinan

pemilikan rumah hunian yang

bertolak dari ketentuan Undang-

Undang Nomor 5 Tahun 1960

tentang Peraturan Dasar Pokok-

pokok Agraria tersebut pada

dasarnya berkaitan dengan status

pemilikan Hak Pakai Atas Tanah

Negara;

c. bahwa dalam perkembangannya praktek penguasaan tanah dalam kaitannya dengan Undang-Undang Nomor 5 T ahun 1960 tentang Peraturan Dasar Pokok-pokok Agraria tersebut dapat pula berlangsung atas dasar perjanjian dengan pemegang hak atas tanah;

d. bahwa sehubungan dengan perkembangan tersebut dipandang perlu menetapkan pengaturan tentang pemilikan rumah tempat tinggal atau hunian oleh orang asing yang berkedudukan di Indonesia dengan Peraturan Pemerintah;"

Lebih lanjut pada bagian PENJELASAN UMUM alinea Pertama sampai dengan alinea ketujuh dinyatakan sebagai berikut:

"Hingga saat ini, terdapat setidaknya dua masalah yang memerlukan kejelasan dalam kaitannya dengan kemungkinan pemilikan rumah hunian oleh orang asing di Indonesia. Pertama, yang berkenaan dengan arahan bahwa orang asing tersebut harus berkedudukan di Indonesia. Kedua, kaitannya dengan status hukum tanah tempat rumah tempat tinggal atau hunian tersebut dibangun.

Arahan bahwa orang asing tersebut harus berkedudukan tersebut dewasa ini dan untuk masa-masa yang akan datang perlu diperjelas dan dijabarkan lebih lanjut. Selain perkembangan keadaan dan kebutuhan yang wajar untuk memberi antisipasi terhadap keterbukaan yang lain merebak ke segala aspek kehidupan, praktek dalam bidang hukum perjanjian pada umumnya dan hukum pertanahan itu sendiri perlu dicermati. Arti daripada arahan mengenai keharusan untuk berkedudukannya di Indonesia, tampaknya kian perlu dijabarkan secara bijaksana.Secara konkrit, tidak perlu harus diartikan sama dengan tempat kediaman atau domisili. Di bidang ekonomi, misalnya orang dapat memiliki kepentingan yang harus dipelihara tanpa harus menunggunya secara fisik, apalagi untuk waktu yang panjang dan secara terus menerus.

Kemajuan di bidang teknologi transportasi dan komunikasi, memungkinkan orang memelihara kepentingan yang dimilikinya di Negara lain tanpa harus menungguinya sendiri.

Kadangkala, mereka cukup hadir berkala. Dalam keadaan seperti itu, yang mereka perlukan adalah fasilitas tempat tinggal atau hunian bila secara berkala tetapi teratur harus datang untuk mengurus atau memelihara kepentingannya. Dengan pertimbangan seperti itu, upaya untuk memperjelas makna "berkedudukan" tadi perlu dilakukan. 
Tinjauan Hukum Pemilikan Apartemen (Satuan Rumah Susun)

Oleh Orang Asing / Warga Negara Asing Di Indonesia

Masalah yang kedua, yang berkaitan dengan status hukum daripada tanah. Undang-Undang Nomor 5 Tahun 1960 tentang Peraturan Dasar Pokok-pokok Agraria menggariskan bahwa sejauh mengenai pemilikan hak atas tanah, yang dapat dimiliki orang asing adalah hak Pakai Atas Tanah Negara. UndangUndang Nomor 16 Tahun 1985 tentang Rumah Susun juga memberikan arahan serupa.

Namun begitu, arahan tersebut pada dasarnya masih terbatas terhadap kemungkinan pemilikan satuan rumah susun. Dengan memperhatikan sifat pengaturan yang terbuka dalam Undang-Undang Nomor 4 T ahun 1992 tentang Perumahan dan Permukiman, sebenarnya juga dimungkinkan pemilikan rumah yang berdiri sendiri. Ini berarti, hal-hal yang berkaitan dengan status hukum tanahnya juga perlu diperjelas.

Dalam praktek hukum, Penguasaan atas bidang tanah juga dapat berlangsung berdasar perjanjian, yang kemudian melahirkan hak-hak baru yang bersifat turunan atas tanah yang sebelumnya telah dimiliki dengan hak tertentu.

Dalam batas-batas yang masih dimungkinkan oleh peraturan perundang-undangan yang berlaku, praktek tersebut tampaknya juga perlu diperhatikan dalam kaitannya dengan kemungkinan pemilikan rumah hunian oleh orang asing di Indonesia."

2. Landasan hukum yang menjadi dasar acuan diterbitkanya PP No. 41 Tahun 1996 ini pada pokoknya adalah sebagai berikut: ${ }^{82}$

1996.

${ }^{82}$ bagian "Mengingat," PP No. 41 Tahun
"1.Pasal 5 ayat (2) Undang-undang Dasar 1945

2. Undang-undang Nomor 5 Tahun 1960 tentang Peraturan Dasar Pokok- pokok Agraria ( Lembaran Negara Tahun 1960 Nomor 104, Tambahan Lembaran Negara Nomor 2043);

3. Undang-undang Nomor $16 \mathrm{~T}$ ahun 1985 tentang Rumah Susun (Lembaran Negara Tahun 1985 Nomor 75, Tambahan Lembaran Negara Nomor 3317);

4. Undang-undang Nomor 4 Tahun 1992 tentang Perumahan dan Permukiman (Lembaran Negara $T$ ahun 1992 Nomor 23, T ambahan Lembaran Negara Nomor 3469);

5. Peraturan Pemerintah Nomor 4 Tahun 1988 tentang Rumah Susun (Lembaran Negara Tahun 1988 Nomor 7, Tambahan Lembaran Negara Nomor 3373);

6. Peraturan Pemerintah Nomor 40 Tahun 1996 tentang Hak Guna Usaha, Hak Guna Bangunan, dan Hak Pakai atas Tanah (Lembaran Negara Tahun 1996 Nomor 58, Tambahan Lembaran Negara Nomor 3643);"

3. Landasan filosofis yang menjadi dasar diterbitkanya PP No. 41 Tahun 1996 ini pada pokoknya adalah sebagai berikut: ${ }^{83}$

"a. bahwa untuk lebih memberikan kepastian hukum mengenai kemungkinan pemilikan tempat tinggal atau hunian oleh orang asing, diperlukan upaya

${ }^{83}$ bagian "Menimbang, sub huruf a." PP No. 41 Tahun 1996. 
penjabaran ketentuan dalam Undang-Undang Nomor 16 Tahun 1985 tentang Rumah Susun, dan Undang-Undang Nomor 4 Tahun 1992 tentang Perumahan dan Permukiman;" "Karena hal-hal tadi, dipandang sudah sepantasnya bila dapat diupayakan penjabaran mengenai kemungkinan pemilikan rumah tempat tinggal atau hunian oleh orang asing di Indonesia." 84

UU No. 16 Tahun 1985 mulai berlaku sejak tanggal 31 Desember 1985 dan tidak ada amanat untuk mengatur lebih lanjut pemilikan rumah tempat tinggal atau hunian oleh orang asing / WNA yang berkedudukan di Indonesia dengan Peraturan Pemerintah, akan tetapi demi kepastian hukum setelah lebih dari 10 (sepuluh) tahun UU No. 16 Tahun 1985 berlaku, Pemerintah memandangn sudah sepantasnya Pemerintah mengaturnya dalam bentuk Peraturan Pemerintah yaitu dalam PP No. 41 Tahun 1996 ini mulai berlaku sejak tanggal 17 Juni 1996

Ketentuan teknis dari PP No. 41 Tahun 1996 adalah adanya Peraturan Menteri Negara Agraria/Kepala Badan Pertanahan Nasional Nomor 7 Tahun $1996^{85}$ Tentang

\footnotetext{
${ }^{84}$ bagian "PENJELASAN UMUM alinea kedelapan,” PP No. 41 Tahun 1996.

${ }^{85}$ Kementerian Negara Agraria/Badan Pertanahan Nasional, Peraturan Menteri Negara Agrarial Kepala Badan Pertanahan Nasional tentang Persyaratan Pemilikan Rumah Tempat Tinggal Atau Hunian Oleh Orang Asing, PMNA/Kepala BPN Nomor 7 Tahun 1996, untuk selanjutnya dalam
}

Persyaratan Pemilikan Rumah Tempat Tinggal Atau Hunian Oleh Orang Asing.

UU yang mengatur rumah susunpun yang semula diatur dalam UU No. 16 Tahun 1986, seiring dengan perkembangan masyarakat, ilmu dan pengetahuan serta teknologi Pemerintah bersama-sama dengan Dewan Perwakilan Rakyat (DPR RI) telah sepakat dan setujui untuk membuat Undang-Undang Rumah Susun yang baru, hal ini ditandai dengan disetujui dan diundangkannya UU No. 20 Tahun 2011.

UU No. 20 Tahun 2011 mulai berlaku sejak tanggal 10 Nopember 2011 dan tidak ada amanat untuk mengatur lebih lanjut pemilikan rumah tempat tinggal atau hunian oleh orang asing / WNA yang berkedudukan di Indonesia dengan Peraturan Pemerintah, akan tetapi demi kepastian hukum setelah lebih dari 4 (empat) tahun UU No. 20 Tahun 2011 berlaku, Pemerintah memandangn sudah sepantasnya Pemerintah mengaturnya dalam bentuk Peraturan Pemerintah yaitu dalam PP No. 103 Tahun 2015 yang mulai berlaku sejak tanggal 28 Desember 2015, yang memuat dan terdiri dari 13 (tiga belas) Pasal.

Apabila dicermati secara PP No. 103 Tahun 2015 diperoleh

penulisan ini disebut / ditulis "PMNA/Ka.BPN Nomor 7 Tahun 1996," atau "PMNA/Ka.BPN No. 7 Tahun 1996." [i: 
Tinjauan Hukum Pemilikan Apartemen (Satuan Rumah Susun)

Oleh Orang Asing / Warga Negara Asing Di Indonesia

beberapa fakta hukum sebagai berikut:

1. Landasan sosiologis yang melatarbelakangi diterbitkan PP No. 103 Tahun 2015 ini pada pokoknya adalah sebagai berikut: ${ }^{86}$

"a. bahwa dalam rangka melaksanakan ketentuan Pasal 42 Undang-Undang Nomor 5 Tahun 1960 tentang Peraturan Dasar Pokok-Pokok Agraria, dan untuk lebih memberikan kepastian hukum pemilikan rumah tempat tinggal atau hunian oleh orang asing yang berkedudukan di Indonesia, maka Peraturan Pemerintah Nomor 41 Tahun 1996 tentang Pemilikan Rumah Tempat Tinggal atau Hunian oleh Orang Asing yang Berkedudukan di Indonesia perlu diganti;

b. bahwa berdasarkan pertimbangan sebagaimana dimaksud dalam huruf a, perlu menetapkan Peraturan Pemerintah tentang Pemilikan Rumah Tempat Tinggal atau Hunian oleh Orang Asing yang Berkedudukan di Indonesia."

Lebih lanjut pada bagian PENJELASAN UMUM alinea Pertama sampai dengan alinea kedua dinyatakan sebagai berikut:

2015

${ }^{86}$ bagian "Menimbang," PP No. 103 Tahun
"Dalam rangka mendukung pembangunan yang semakin meningkat seiring kerjasama Indonesia dengan negara-negara sahabat, dan meningkatnya jumlah Orang Asing yang bekerja dan menjalankan usahanya di Indonesia, mengakibatkan permintaan kebutuhan rumah tempat tinggal atau hunian bagi Orang Asing semakin meningkat, sehingga perlu dibuat kebijakan yang memberikan kepastian hukum serta kemudahan dalam pemberian pelayanan maupun izin memperoleh hak atas tanah untuk rumah tempat tinggal atau hunian bagi Orang Asing."

Kemudahan yang diberikan tersebut dilakukan dengan tetap memegang prinsip-prinsip pertanahan di antaranya prinsip nasionalitas, bahwa hanya Warga Negara Indonesia yang dapat memiliki Hak Milik, sedangkan Orang Asing hanya dapat diberikan hak atas tanah berupa Hak Pakai dan Hak Sewa."

2. Landasan hukum yang menjadi dasar acuan diterbitkanya PP No. 103 Tahun 2015 ini pada pokoknya adalah sebagai berikut: 87

"1. Pasal 5 ayat (2) UndangUndang Dasar Negara Republik Indonesia Tahun 1945; 
2. Undang-Undang Nomor 5

Tahun 1960 tentang

Peraturan Dasar Pokok-

Pokok Agraria (Lembaran

Negara Republik Indonesia

Tahun 1960 Nomor 104,

Tambahan Lembaran

Negara Republik Indonesia

Nomor 2043);

3. Undang-Undang Nomor 6

Tahun 2011 tentang

Keimigrasian (Lembaran

Negara Republik Indonesia

Tahun 2011 Nomor 52,

Tambahan Lembaran

Negara Republik Indonesia

Nomor 5216)"

3. Landasan filosofis yang menjadi dasar diterbitkanya PP No. 103 Tahun 2015 ini pada pokoknya adalah sebagai berikut: ${ }^{88}$

"a. bahwa dalam rangka melaksanakan ketentuan

Pasal 42 Undang-Undang Nomor 5 Tahun 1960 tentang Peraturan Dasar Pokok-Pokok Agraria, dan untuk lebih memberikan kepastian hukum pemilikan rumah tempat tinggal atau hunian oleh orang asing yang berkedudukan di Indonesia, maka Peraturan Pemerintah Nomor 41 Tahun 1996 tentang Pemilikan Rumah Tempat Tinggal atau Hunian oleh Orang Asing yang Berkedudukan di Indonesia perlu diganti;"

${ }^{88}$ bagian "Menimbang, sub huruf a." PP No. 103 Tahun 2015.
"Sehubungan dengan hal tersebut, maka perlu adanya pembatasan terhadap rumah tempat tinggal atau hunian yang akan diberikan kepada Orang Asing." 89

Satu tahun kemudian ketentuan teknis dari PP No. 103 Tahun 2015 diatur lebih lanjut dalam Peraturan Menteri Agraria dan Tata Ruang / Kepala Badan Pertanahan Nasional Nomor 13 Tahun $2016^{90}$ tentang Tata Cara Pemberian, Pelepasan, dan Pengalihan Hak Atas Pemilikan Rumah Tinggal Atau Hunian oleh Orang Asing yang Berkedudukan di Indonesia sebagaimana telah dicabut dan diganti dengan Peraturan Menteri Agraria Dan Tata Ruang/Kepala Badan Pertanahan Nasional Republik Indonesia Nomor 29 Tahun $2016^{91}$ Tentang

\footnotetext{
${ }^{89}$ bagian "PENJELASAN UMUM alinea ketiga," PP No. 103 Tahun 2015.

${ }^{90}$ Kementerian Agraria Dan Tata Ruang/Badan Pertanahan Nasional Republik Indonesia, Peraturan Menteri Agraria dan Tata Ruang/Kepala Badan Pertanahan Nasional Tentang Tata Cara Pemberian, Pelepasan, dan Pengalihan Hak Atas Pemilikan Rumah Tinggal Atau Hunian oleh Orang Asing yang Berkedudukan di Indonesia, Peraturan Menteri ATR/Kepala BPN Nomor 13 Tahun 2016, untuk selanjutnya dalam penulisan ini disebut / ditulis "Permen ATR/Ka.BPN Nomor 13 Tahun 2016," atau "Permen ATR/Ka.BPN No. 13 Tahun 2016."

${ }^{91}$ Kementerian Agraria Dan Tata Ruang/Badan Pertanahan Nasional Republik Indonesia, Peraturan Menteri Agraria dan Tata Ruang/Kepala Badan Pertanahan Nasional Tentang Tata Cara Pemberian, Pelepasan, Atau Pengalihan Hak Atas Pemilikan Rumah Tempat Tinggal Atau Hunian Oleh Orang Asing Yang Berkedudukan Di Indonesia, Perarutan Menteri ATR/Kepala BPN Nomor 29 Tahun 2016, untuk selanjutnya dalam penulisan ini disebut / ditulis "Permen
} 
Tata Cara Pemberian, Pelepasan, Atau Pengalihan Hak Atas Pemilikan Rumah Tempat Tinggal Atau Hunian Oleh Orang Asing Yang Berkedudukan Di Indonesia.

\section{b. Pemilikan rumah susun (apartemen, condominium) oleh orang Asing / warga negara Asing di Indonesia}

Orang Asing/WNA dapat memiliki unit SRS yang dibangun di atas bidang tanah negara dengan jenis hak atas tanahnya berupa Hak Pakai atas Tanah Negara, berdasarkan Pasal 4 sub huruf b PP No. 103 Tahun 2015 sebagai Pengganti dari Pasal 2 sub angka 2 PP No. 41 Tahun 1996 Jo. Pasal 17 UU No. 20 Tahun 2011 serta Permen ATR/Ka.BPN No. 29 Tahun 2016 yang mulai berlaku pada tanggal diundangkan, pada tanggal 26 September 2016.

\section{Dengan demikian, Orang Asing/WNA memenuhi syarat} subjektif pemilikan unit SRS dengan objek berupa unit SRS yang berdiri atau dibangun diatas bidang tanah berupa Hak Pakai atas Tanah Negara sebagai syarat objektif dalam pemilikan unit SRS di Indonesia.

Proses jual beli unit SRS (apartemen, condominium) sebelum pembangunan SRS (apartemen, condominium) selesai dapat dilakukan melalui PPJB (Perjanjian Pengikatan Jual Beli) yang dibuat dihadapan Notaris, berdasarkan ketentuan Pasal 43 UU No. 20 Tahun

ATR/Ka.BPN Nomor 29 Tahun 2016," atau "Permen ATR/Ka.BPN No. 29 Tahun 2016." Permen ATR/Ka.BPN No. 29 Tahun 2016 ini ditetapkaniseppada tanggal 19 September 2016, mulai berlaku pada tanggal diundangkan, pada tanggal 26 September 2016.
2011, setelah memenuhi persyaratan kepastian atas status kepemilikan tanah, kepemilikan IMB, ketersediaan prasarana, sarana, dan utilitas umum, keterbangunan paling sedikit $20 \%$ (dua puluh persen), dan hal yang diperjanjikan.

Proses jual beli, yang dilakukan sesudah pembangunan rumah satuan rumah susun (apartemen, condominium) selesai, dilakukan melalui Akta Jual Beli (AJB) dihadapan PPAT yang berwenang, berdasarkan ketentuan Pasal 44 UU No. 20 Tahun 2011 Jo. PP No. 37 Tahun 1998 dan PP No. 24 Tahun 2016, apabila telah diterbitkan Sertifikat Laik Fungsi, dan SHM satuan rumah susun (apartemen, condominium) atau SKBG sarusun.

Hak kepemilikan atas SRS (apartemen, condominium), berdasarkan ketentuan Pasal 46 UU No. 20 Tahun 2011, merupakan hak milik atas sarusun yang bersifat perseorangan yang terpisah dengan hak bersama atas bagian bersama, benda bersama, dan tanah bersama, yang dihitung berdasarkan atas NPP (Nilai Perbandingan Proporsional).

Sebagai Tanda Bukti Kepemilikan atas satuan rumah susun (apartemen, condominium) di atas Hak Pakai atas tanah negara diterbitkan SHMSRS oleh kantor pertanahan kabupaten/kota yang berwenang, berdasarkan ketentuan Pasal 47 UU No. 20 Tahun 2011, bagi setiap orang yang memenuhi syarat sebagai pemegang hak atas tanah, yang merupakan satu kesatuan yang tidak terpisahkan yang terdiri atas salinan buku tanah dan surat ukur atas hak tanah bersama sesuai dengan ketentuan peraturan perundang - undangan, 
gambar denah lantai pada tingkat rumah susun bersangkutan yang menunjukkan sarusun yang dimiliki, dan pertelaan mengenai besarnya bagian hak atas bagian bersama, benda bersama, dan tanah bersama bagi yang bersangkutan.

\section{G.Penutup}

\section{A. Kesimpulan}

Setelah menguraikan, mengkaji dan menganalisis pengaturan hukum pemilikan apartemen oleh warga negara Asing di Indonesia, maka dapat disimpulkan sebagai berikut:

Pertama pengaturan hukum pemilikan apartemen oleh warga negara Asing di Indonesia telah cukup memadai, karena telah diatur ada Undang-Undang yang mengaturnya yaitu UU No. 20 Tahun 2011, PP No. 103 Tahun 2015 maupun Permen ATR/Ka.BPN No. 29 Tahun 2016, pada akhirnya akan memberikan kepastikan hukum bagi warga negara Asing.

Kedua, Orang Asing/WNA dapat memiliki satuan rumah susun (apartemen, condominium) yang dibangun hanya di atas bidang tanah hak pakai atas tanah negara. Sedangkan terhadap satuan rumah susun (apartemen, condominium) yang dibangun di atas bidang tanah hak milik, hak guna bagunan dan hak guna usaha serta hak pakai di atas hak milik, Orang Asing/WNA tidak dapat memilikinya.

\section{B. Rekomendasi}

Berdasarkan kesimpulan yang telah dirumuskan di atas, maka dapat disarankan sebagai berikut:

Pertama perlu dilakukan sosialisasi yang lebih intensif atas ketentuan hukum yang mengatur pemilikan satuan rumah susun (apartemen, condominium) oleh warga negara Asing di Indonesia yang telah diatur dalam Undang-Undang yaitu UU No. 20 Tahun 2011, PP No. 103 Tahun 2015 maupun Permen ATR/Ka.BPN No. 29 Tahun 2016.

Kedua perlu dilakukan pembaharuan UU No. 20 Tahun 2011 agar Orang Asing/WNA dapat memiliki satuan rumah susun (apartemen, condominium) yang dibangun hanya di atas bidang tanah hak pakai atau hak guna banguan atas tanah negara, hal ini untuk menarik investasi warga negara Asing dalam sektor bidang rumah susun (apartemen, condominium).

\section{Daftar Pustaka}

I. Buku:

Asikin, Amirudin dan Zainal. Pengantar Metode Penelitian Hukum, Ed. 1, Cet. 3, Jakarta: PT Raja Grafindo Persada, 2006

Creswell, John W. Research Design of Qualitative \& Quantitative Approches, dalam Natasya Yunita Sugiastuti, Tradisi Hukum Cina: Negara Dan Masyarakat (Studi Mengenai Peristiwa-peristiwa Hukum di Pulau Jawa Zaman Kolonial (1870-1942), Cet. 1, Jakarta: Program Pasca Sarjana Fakultas Hukum Universitas Indonesia, 2003, hlm. 19.

Denzin, Norman K. \& Yvona S. Lincoln, ed. Handbook of Qualitative Research dikutip dari Natasya Yunita Sugiastuti, Tradisi Hukum Cina: Negara Dan Masyarakat (Studi Mengenai Peristiwa-peristiwa Hukum 
di Pulau Jawa Zaman Kolonial (18701942), Cet. 1, Jakarta: Program Pasca Sarjana Fakultas Hukum Universitas Indonesia, 2003, hlm. 19.

Hasan, Fuad. dan Koentjaraningrat, "Beberapa Azas Metodologi Ilmiah," dalam Koentjaraningrat (Ed.), Metode-metode Penelitian Masyarakat, Cet. 9, Jakarta: PT. Gramedia Jakarta, 1989

Hutagalung, Arie S. Condominium Dan Permasalahannya, Ed. 1, Cet. 1, (Depok : Badan Penerbit Fakultas Hukum Universitas Indonesia, 1998

Ibrahim, Jhonny. Teori Dan Metodologi Penelitian Hukum Normatif, Ed. Revisi, Cet. 3, Malang: Bayumedia Publishing, 2007

Koentjaraningrat (Ed.), Metode-metode Penelitian Masyarakat, Cet. 9, Jakarta: PT. Gramedia Jakarta, 1989

Kuswahyono, Imam. Hukum Rumah Susun

: Suatu Bekal Pengantar Pemahaman, Cet. 1, Malang : Bayu Media Publishing, 2004.

Mamudji, Sri. Et.al, Metode Penelitian Dan Penulisan Hukum, Cet. 1, Depok: Badan Penerbit FH UI, 2005.

Marzuki, Peter Mahmud. Penelitian Hukum, Ed. Revisi, Cet. 8, Jakarta : Kencana, Prenada Media Grup, 2013

Muhammad, Abdulkadir. Hukum dan Penelitian Hukum, Cet. 1, (Bandung : PT. Citra Aditya Bakti, 2004

Perangin, Effendi. Hukum Agraria Indonesia: Suatu Telaah Sudut Pandang Praktisi Hukum, Cet. 1, Jakarta : Rajawali, 1986.

Soekanto, Soerjono. Pengantar Penelitian Hukum, Cet. 3, Jakarta: UI Press, 1986
Soekanto, Soerjono dan Sri Mamudji, Penelitian Hukum Normatif Suatu Tinjauan Singkat, Ed. 1, Cet. 5, Jakarta : PT. RajaGrafindo Persada, 2001

Soemitro, Ronny Hanitijo. Metodologi Penelitian Hukum Dan Jurimetri, Cet. ke-3, Jakarta: Ghalia Indonesia, 1988.

Subagyo, Joko. Metode Penelitian Dalam Teori Dan Praktek, (Jakarta : Rineka Cipta, 2004

Sugiastuti, Natasya Yunita. Tradisi Hukum Cina: Negara Dan Masyarakat (Studi Mengenai Peristiwa-peristiwa Hukum di Pulau Jawa Zaman Kolonial (18701942), Cet. 1, Jakarta: Program Pasca Sarjana Fakultas Hukum Universitas Indonesia, 2003

Sunggono, Bambang. Metodologi Penelitian Hukum (Suatu Pengantar), Ed. 1., Cet. 3, (Jakarta: PT. Raja Grafindo Persada, 2001

Sunarjati Hartono, C. F. G. Penelitian Hukum Di Indonesia Pada Akhir Abad Ke-20, Cet. 1, Bandung : Alumni, 1994

Surakhmad, Winarno. Pengantar Penelitian Ilmiah, Dasar Metode dan Teknik, Ed. 7, Bandung: Tarsito, 1984

Waluyo, Bambang. Penelitian Hukum Dalam Praktek, Ed. 1, Cet. 2, (Jakarta : Sinar Grafika, 1996

II. Perundang-undagan:

Indonesia, Undang-Undang Tentang Peraturan Dasar Pokok-Pokok Agraria, UU Nomor 5 Tahun 1960, Lembaran Negara Republik Indonesia Tahun 1960 Nomor 104, Tambahan Lembaran Negara Republik Indonesia Nomor 2043.

------, Undang-Undang Tentang Rumah Susun, UU Nomor 16 Tahun 1985, 
Tinjauan Hukum Pemilikan Apartemen (Satuan Rumah Susun)

Oleh Orang Asing / Warga Negara Asing Di Indonesia

LN RI Tahun 1985 Nomor 75, TLN RI Nomor 3318.

------, Undang-Undang Tentang Bangunan Gedung, UU Nomor 28 Tahun 2002, LN RI Tahun 2002 Nomor 134, TLN RI Nomor 4247.

------, Undang-Undang Tentang Administrasi Kependudukan, UU Nomor 23 Tahun 2006, LN RI Tahun 2006 Nomor 124, TLN RI Nomor 4674.

-----, Undang-Undang Tentang

Kewarganegaraan, UU Nomor 12 Tahun 2006, LN RI Tahun 2006 Nomor 63, TLN RI Nomor 4634.

------, Undang-Undang Tentang Perumahan Dan Kawasan Permukiman, UU Nomor 1 Tahun 2011, LN RI Tahun 2011 Nomor 17, TLN RI Nomor 5188.

------, Undang-Undang Tentang Rumah Susun, UU Nomor 20 Tahun 2011, LN RI Tahun 2011 Nomor 108, TLN RI Nomor 5252.

------, Undang-Undang Tentang Perubahan Atas Undang-Undang Nomor 23 Tahun 2006 Tentang Administrasi Kependudukan, UU Nomor 24 Tahun 2013, LN RI Tahun 2013 Nomor 232, TLN RI Nomor 5475.

------, Undang-Undang Tentang Jasa Konstruksi, UU Nomor 2 Tahun 2017, LN RI Tahun 2017 Nomor 111, TLN RI Nomor 6018.

Indonesia, Peraturan Pemerintah Tentang Pendaftaran Tanah, PP Nomor 10 Tahun 1961, LN RI Tahun 1961 Nomor 28, TLN RI Nomor 2171

------, Peraturan Pemerintah Tentang Penunjukan Badan-badan Hukum Yang Dapat Mempunyai Hak Milik Atas Tanah, PP Nomor 38 Tahun 1963, LN RI Tahun 1963 Nomor 61, TLN RI Nomor 2555
Peraturan Pemerintah Tentang Rumah Susun, PP Nomor 4 Tahun 1988, LN RI Tahun 1988 Nomor 7, TLN RI Nomor 3372

------, Peraturan Pemerintah Tentang Hak Guna Bangunan, Hak Guna Usaha, dan Hak Pakai atas Tanah, PP Nomor 40 Tahun 1996, LN RI Tahun 1996 Nomor 58, TLN RI Nomor 3643

Peraturan Pemerintah Tentang Pemilikan Rumah Tempat Tinggal atau Hunian oleh Orang Asing yang Berkedudukan di Indonesia, PP Nomor 41 Tahun 1996, LN RI Tahun 1996 Nomor 59, TLN RI Nomor 3644

------, Peraturan Pemerintah Tentang Pendaftaran Tanah, PP Nomor 24 Tahun 1997, LN RI Tahun 1997 Nomor 59, TLN RI Nomor 3696

------, Peraturan Pemerintah Tentang Peraturan Jabatan Pejabat Pembuat Akta Tanah, PP Nomor 37 Tahun 1998, LN RI Tahun 1998 Nomor 52, TLN RI Nomor 3746

------, Peraturan Pemerintah Tentang Pemilikan Rumah Tempat Tinggal atau Hunian oleh Orang Asing yang Berkedudukan di Indonesia, PP Nomor 103 Tahun 2015, LN RI Tahun 2015 Nomor 325, TLN RI Nomor 5793.

------, Peraturan Pemerintah Tentang Perubahan Peraturan Pemerintah Tentang Peraturan Jabatan Pejabat Pembuat Akta Tanah, PP Nomor 24 Tahun 2016, LN RI Tahun 2016 Nomor 120, TLN RI Nomor 5893

Kementerian Agraria, Peraturan Menteri Agraria Tentang Pelaksanaan Konversi Hak Penguasaan Atas Tanah Negara Dan Kebijaksanaan, PMA Nomor 9 Tahun 1965 
Tinjauan Hukum Pemilikan Apartemen (Satuan Rumah Susun) Oleh Orang Asing / Warga Negara Asing Di Indonesia

Kementerian Negara Agraria/Badan Pertanahan Nasional, Peraturan Menteri Negara Agrarial Kepala Badan Pertanahan Nasional tentang Persyaratan Pemilikan Rumah Tempat Tinggal Atau Hunian Oleh Orang Asing, PMNA/Kepala BPN Nomor 7 Tahun 1996

Kementerian Negara Agraria/Kepala Badan Pertanahan Nasional, Peraturan Menteri Negara Agraria/Kepala Badan Pertanahan Nasional tentang Ketentuan Pelaksanaan Peraturan Pemerintah Nomor 24 Tahun 1997 tentang Pendaftaran Tanah, PMNA/Kepala BPN Nomor 3 Tahun 1997

Kementerian Negara Agraria/Kepala Badan Pertanahan Nasional, Keputusan Menteri Negara Agraria/Kepala Badan Pertanahan Nasional tentang Perubahan Hak Milik Menjadi Hak Guna Bangunan atau Hak Pakai dan Hak Guna Bangunan Menjadi Hak Pakai, Kep.MNA/Kepala BPN Nomor 16 Tahun 1997

Kementerian Negara Agraria/Kepala Badan Pertanahan Nasional, Peraturan Menteri Negara Agraria/Kepala Badan Pertanahan Nasional tentang Tata Cara Pemberian Dan Pembatalan Hak Atas Tanah Negara Dan Hak Pengelolaan, PMNA/Kepala BPN Nomor 9 Tahun 1999

Badan Pertanahan Nasional, Peraturan Kepala Badan Pertanahan Nasional tentang Ketentuan Pelaksanaan Peraturan Pemerintah Nomor 37 Tahun 1998 Tentang Peraturan Jabatan Pejabat Pembuat Akta Tanah, Peraturan Kepala BPN Nomor 1 Tahun 2006

Badan Pertanahan Nasional, Peraturan Kepala Badan Pertanahan Nasional tentang Perubahan Atas Peraturan Kepala Badan Pertanahan Nasional Nomor 1 Tahun 2006 tentang Ketentuan Pelaksanaan Peraturan Pemerintah Nomor 37 Tahun 1998 Tentang Peraturan Jabatan Pejabat Pembuat Akta Tanah, Peraturan Kepala BPN Nomor 23 Tahun 2009

Badan Pertanahan Nasional, Peraturan Kepala Badan Pertanahan Nasional tentang Perubahan Atas Peraturan Menteri Negara Agraria/Kepala Badan Pertanahan Nasional Nomor 3 Tahun 1997 tentang Ketentuan Pelaksanaan Peraturan Pemerintah Nomor 24 Tahun 1997 tentang Pendaftaran Tanah, Perka.BPN Nomor 8 Tahun 2012.

Kementerian Agraria Dan Tata Ruang/Badan Pertanahan Nasional Republik Indonesia, Peraturan Menteri Agraria dan Tata Ruang/Kepala Badan Pertanahan Nasional Tentang Tata Cara Pemberian, Pelepasan, dan Pengalihan Hak Atas Pemilikan Rumah Tinggal Atau Hunian oleh Orang Asing yang Berkedudukan di Indonesia, Peraturan Menteri ATR/Kepala BPN Nomor 13 Tahun 2016

Kementerian Agraria Dan Tata Ruang/Badan Pertanahan Nasional Republik Indonesia, Peraturan Menteri Agraria dan Tata Ruang/Kepala Badan Pertanahan Nasional Tentangis: Pemberian, Pelepasan, Atau Pengalihan Hak Atas Pemilikan Rumah Tempat Tinggal Atau Hunian Oleh Orang Asing Yang Berkedudukan Di Indonesia, Peraturan Menteri ATR/Kepala BPN Nomor 29 Tahun 2016. 